\title{
Value of the Storm-Protection Function of Sundarban Mangroves in Bangladesh
}

\author{
A. H. M. Raihan Sarker ${ }^{1}$, Mohammad Nur Nobi ${ }^{2}$, Eivin Røskaft ${ }^{3}$, David J. Chivers ${ }^{4} \& \mathrm{Ma} \mathrm{Suza}^{5}$ \\ ${ }^{1}$ Institute of Forestry and Environmental Sciences, University of Chittagong, Chittagong, Bangladesh \\ ${ }^{2}$ Department of Economics, University of Chittagong, Chittagong, Bangladesh \\ ${ }^{3}$ Department of Biology, Norwegian University of Science and Technology, NTNU, Trondheim, Norway \\ ${ }^{4}$ Selwyn College, University of Cambridge, Cambridge, UK \\ ${ }^{5}$ Universidade de Lisboa Instituto Superior Técnico Campus Alameda, Portugal \\ Correspondence: Dr. A. H. M. Raihan Sarker, Institute of Forestry and Environmental Sciences, University of \\ Chittagong, Chittagong \#4331, Bangladesh. Tel: 88-013-1766-5799. E-mail: dr.raihan.sarker@cu.ac.bd
}

Received: March 19, 2020 Accepted: April 8, 2020 Online Published: May 30, 2020

doi:10.5539/jsd.v13n3p128 URL: https://doi.org/10.5539/jsd.v13n3p128

\begin{abstract}
Globally mangrove forests are among the most severely threatened ecosystems. The protection value of mangrove forests is important for policy makers as a means of increasing forestation in coastal areas. Only a few economic studies have estimated the protective value of mangrove ecosystems. None have estimated the value of this service in the Sundarban of Bangladesh. In this study, we estimated the economic value of storm-protection services of the Sundarban Reserve Forest during cyclone Sidr in 2007 by valuing and comparing the economic damage and losses of households at two sites (i.e., near the Sundarban and far from the Sundarban). In total, 1,525 households from 9 upazillas (sub-districts) were sampled, all located within $1 \mathrm{~km}$ distance of the embankment. Applying the Damage-Cost-Avoided (DCA) method, the storm-protection value of the Sundarban is estimated at USD 543.30 million. The estimated value of the damage cost avoided per household (as of 2015 consumer price) also implies that the installation of a one-km width of intact mangrove forest can save USD 396 to each household during cyclones and storm surges. Conservation and restoration of the ecological status of Sundarban is, therefore, urgently needed for the continued existence and sustainable use of Sundarban's ecosystem services in the long term.
\end{abstract}

Keywords: cyclone Sidr, mangrove forest, protection service, Sundarban, economic value

\section{Introduction}

The Sundarban Reserve Forest (SRF) plays a significant role in the Bangladesh's economy since wood and nonwood forest products are frequently harvested from the Sundarban. But the Sundarban's mangrove ecosystems also provide substantial indirect benefits (Vincent \& Das, 2009). For instance, the mangrove forests and plantations play a large role in mitigating the destructive forces of winds and tidal bores, thereby reducing human casualties and property damage (Shine \& Klemm, 1999). Brander et al. (2006) stated that almost onethird of mangrove areas (about 35\%) will be lost between 2000 and 2050 in Southeast Asia. Bangladesh also lost one third of its mangroves since the devastating cyclone Sidr attacked the Sundarban in 2007 (Nandy et al., 2013). Siddiqi (2001) has discussed that mangrove forests in Bangladesh face several problems, including local people's dependency on the services provided by such forests. Cyclones and storm surge are the major threats to the SRF, along with erosion, flood, salinity intrusion, expansion of shrimp culture, ecosystem degradation, pollution and climate change (Das, 2011). Repeated cyclones confront coastal residents, and the threats to biodiversity could also make the SRF further vulnerable in future (Nandy et al., 2013). If climate change effects increase the vulnerability as in 2007 , and the same flow of resource collection continues, then the Sundarban will become very threatened, and, in the long run, its very existence will come into question.

Storm surges are perhaps the most destructive natural hazards in low-lying coastal areas, causing loss of life and property (Alongi, 2002; Flather, 2001; Storch \& Woth, 2008). As a result of global climate change and sea level rise, greater frequency and intensification of tropical cyclones may drive storm surge and flooding in many lowlying coastal areas (Mousavi et al., 2011). Although cyclones and tidal surges are common in Bangladesh due to 
its geographical position, cyclone Sidr was a vicious cyclone that struck different parts of the Sundarban on $15^{\text {th }}$ November 2007 with an average wind speed of $223 \mathrm{~km} / \mathrm{h}$ and caused extensive damage to the reserve forest, which will take at least 40 years to recover (Manil \& Mia, 2007). It affected the livelihoods of 8.9 million people, 0.65 million ha of cropland, and 1.2 million houses and the total damage and losses were estimated at USD 1.67 billion (Paul, 2009). Cyclone Sidr struck the Sundarban first, before it reached human settlement zones, and thus it can be assumed that the forest reduced the strength of the wind and surge through its ability to attenuate waves and buffer winds as is evident in several studies (Barbier, 2007; Barbier, 2011; Das, 2011; Erwin, 2009; McIvor et al., 2012). Thus, understanding the protection value of mangroves against storms is important for policy makers to understand the costs of not having this important resource, and to determine the vulnerability of poor communities living in and around the Sundarban.

After Cyclone Sidr, economists, ecologists and policy-makers argued about the contribution of the SRF's protection roles against natural disasters to the Bangladesh economy. Since the value of the protection service of the Sundarban has not been estimated, the goal in this study was to do just that: assess the economic value of storm-protection services of the Sundarban during cyclones, storms, and tidal surges by valuing and comparing the economic damage and losses of households at two sites (i.e., near the Sundarban and far from the Sundarban), caused by cyclone Sidr. To do this, we assessed (i) the value per hectare of the SRF protection at the household level, and (ii) the damage and losses in communities near SRF and those far from the forest, to demonstrate that those living near the SRF were affected less than those who lived far from the forest. Finally, recommendations are made for the conservation of the SRF, considering its protection role.

\section{Materials and Methods}

\subsection{Site Description}

The Sundarban Reserve Forest (SRF) is situated along the coastline of the Bay of Bengal in the south-western region (i.e., Khulna division) of Bangladesh, and it was declared as World Heritage Site by UNESCO in 1997. The total area of the forest is 603,000 ha, consisting of three wildlife sanctuaries: Sundarban West $(71,303 \mathrm{ha})$, Sundarban East (31,227 ha) and Sundarban South (36,970 ha).

The eastern and northern parts of the SRF are surrounded by five administrative districts: Khulna, Satkhira, Bagerhat, Pirojpur, and Barguna, which include 10 upazilas (sub-districts), 152 unions and 1,303 villages. The total population of the whole area is about 3.5 million (BIDS, 2010). According to the Bangladesh Environment Conservation Act 1995, a 10-km-wide area of approximately 175,000 ha was declared by the Ministry of Environment and Forest as an Ecologically Critical Area (ECA) on 30 August 1999, this area legally separating the SRF from the surrounding unions and villages in the northern and the eastern parts. The western part of the forest is shared between India and Bangladesh, with separate management authorities on each side of the border. The southern part of the forest is beside the shoreline of the Bay of Bengal.

\subsection{Data Collection and Analysis}

Cyclone Sidr struck the south-western Bangladesh districts of Bagerhat, Khulna, Satkhira, and Barguna. All the districts are located near the SRF and have forested lands except Barguna (Fig. 1). Thus, to estimate the stormprotection value of the SRF, we considered Khulna, Satkhira, and Bagerhat as the treatment zone (TZ) and Barguna as the control zone (CZ). We used the entire area of SRF to evaluate a protection value of the mangrove forest, then analysed the economic damage and losses near the mangrove forests (i.e., TZ), compared to the damage and losses to the area far from the mangrove forest (i.e., CZ), to reinforce the hypothesis that mangroves reduce damage and losses of assets.

Altogether 1,525 households, located within $1 \mathrm{~km}$ of the embankments were surveyed. A semi-structured questionnaire was used that included questions on households' socio-economic status, human casualties, and damage to houses and crops. A systematic sampling plan was used for collecting data through interviewing respondents $(n=1,525)$ over the age of 18 across the study sites. For avoiding displacement factors, at first, one respondent who lived near the embankment during cyclone Sidr was selected randomly, and then we asked $\mathrm{him} /$ her to suggest other persons who lived near the embankment during the cyclone. Respondents were interviewed face-to-face, and they were chosen from both sides of the embankments. For each household, we recorded Global Information System coordinates. After coding and digitizing the collected data, we used STATA 12 and SPSS 20.0 to analyse it. Differences in socio-economic conditions of respondents and the damage and losses caused by cyclone Sidr were explored using one-way ANOVA and Chi-square $\left(\chi^{2}\right)$ tests and the significance level was set at $\mathrm{p}=0.05$. 


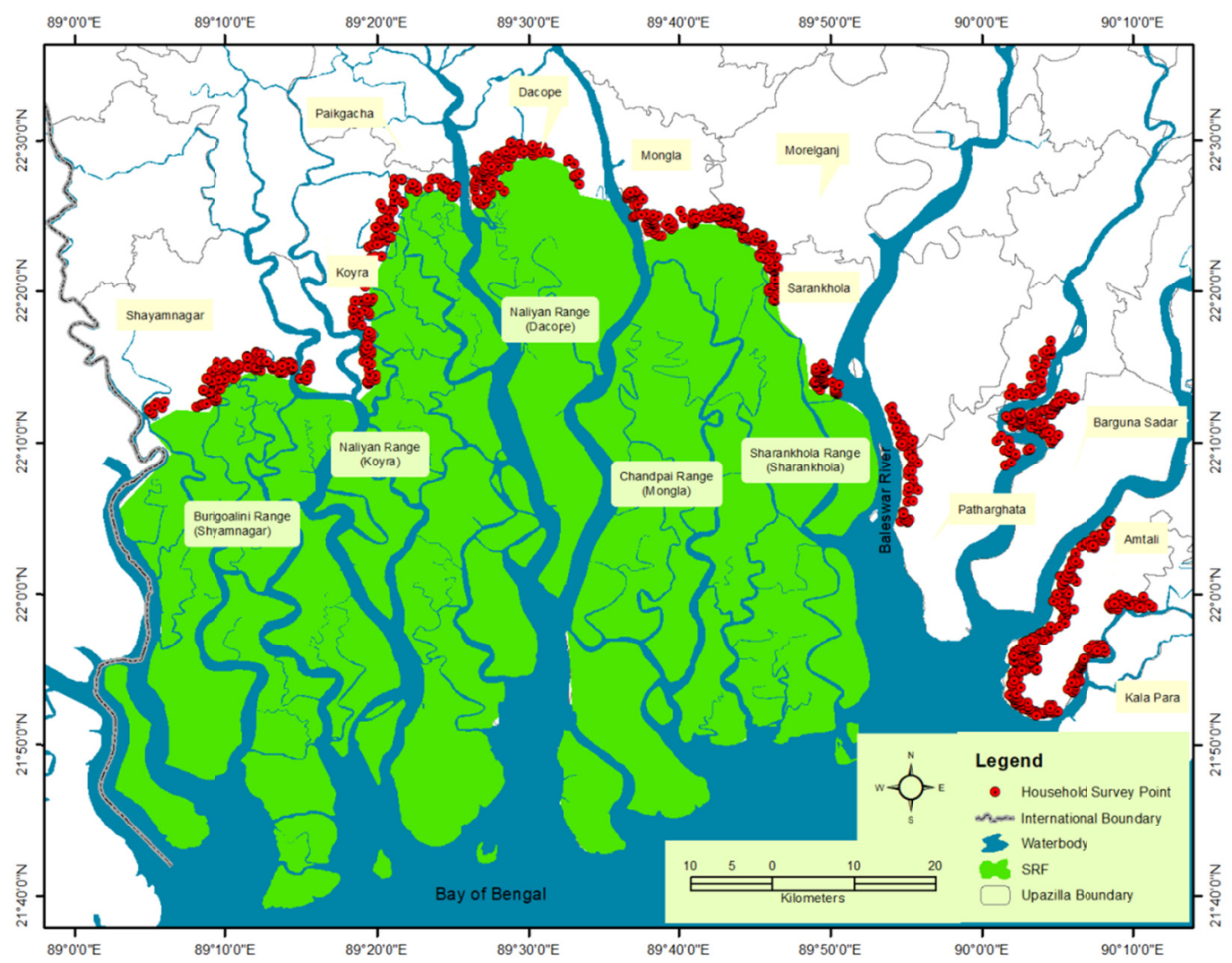

Figure 1. Map showing the study sites

\subsection{Valuing the Protection Role of Mangroves - Use of Damage-Cost-Avoided Method}

The Damage-Cost-Avoided (DCA) method estimates the values of ecosystem services based on either (i) the cost required to protect the environmental goods to avoided damages, (ii) the cost of replacing ecosystems, or (iii) the cost of providing substitute services. This method is used to value economic services (Badola et al., 2003). The width of mangrove forest plays a significant role in protecting and reducing saline water flow during the cyclones (Das \& Vincent, 2009).

We used damage-cost function to determine the DCA per household due to the existence of the SRF and its role as a buffer to cyclones and sea surges by estimating the value of damage in relationship to the width of the forests. With the value of coefficient of the width of the forest from the estimated result, we identified the DCA for the households. Then, this value (i.e., DCA per household) was multiplied with the total number of households in the treatment zone (i.e., closer to SRF) to estimate the total DCA as the value of protection services of SRF.

\subsection{Theoretical Model of Damage-Cost-Avoided Method}

Usually, two steps are considered in the Damage-Cost-Avoided (DCA) method (Wooldridge, 2003). First, the damage-cost function is estimated with the help of meteorological, arboricultural, and socio-economic variables. Second, estimation of the dollar value of potential DCA is actually the protection value. The meteorological and arboricultural variables in the damage function are velocity of wind, heights of storm surges, width of the forest and distance of the households from the coast, while the socio-economic variables are associated with the loss of property, respondents' knowledge about the signal of the storm, district dummy, location of the house, and types of the houses.

As mentioned above, we collected the socio-economic variables in terms of household-level damage data by conducting surveys of households in the affected areas. Monetary damages were estimated by adding the costs associated with reconstructing houses, market value of the crops/shrimp farms and livestock, and all other 
properties during the cyclone. The damage cost was then used in the regression equation to estimate the damage function applying a number of explanatory variables.

The explanatory variables for damage function were width of forest, wind velocity, monthly family income, got signal $(1=$ household got the warning signal of the cyclone and $0=$ did not get the warning signal), location of house in respect to embankment ( $d_{1}=$ house is located inside the embankment and $d_{2}=$ house is located outside the embankment), house types dummy $\left(M_{1}=\right.$ otherwise Kacha, $M_{2}=$ tin-shed, $M_{3}=$ semi-pacca, and $M_{4}=$ pacca $)$, district dummy (district has the protection of mangrove; $D D_{I}=$ Bagherhat, $D D_{3}=$ Khulna and $D D_{4}=$ Satkhira, and district has no protection of the mangrove; $D D_{2}=$ Barguna), and distance from the coast. Moreover, the height of storm surges is also significantly responsible for the damages, but we did not include this variable into the model because of the lack of accuracy in measurement. We have requested the respondents to assume the height of the storm surges, but in most of the cases they couldn't measure the exact height of the surges during cyclone Sidr. Thus, the theoretical model for damage function is described as in formula 1;

Damage $=f$ (width, velocity, mfincome, gotsignal, hlocationdummy, htypesdummy, districtdummy, dist-coast)

The specific empirical model of the damage function is thus as in formula 2;

$$
\begin{aligned}
& D=\beta_{1} \text { width }+\beta_{2} \text { velocity }+\beta_{3} \text { mfincome }+\beta_{4} \text { gotsignal }+\beta_{5} \text { locationdummy }+\beta_{6} \text { htypesdummy }+\beta_{7} \text { districtdummy } \\
& +\beta_{8} \text { dist-coast }+\varepsilon
\end{aligned}
$$

The expected signs of the coefficient of explanatory variables in damage function are as follows: width of the forest (-), velocity $(+)$, monthly family income of the households $(+)$, dist-coast $(-)$, location of the house in respect to embankment (+/-), house types (+/-), received the warning of the cyclone signal (-), district dummy ($/+)$ and distance from the coast (-). Here $\varepsilon$ refers the error term.

We assumed that the wind velocity was the same at the entry points of the cyclone Sidr along the coastlines but was different where the mangrove forest was present. As a result, damages were expected to be lower in the treatment zone because of the presence of the SRF, which reduced the velocity of stormy wind compared to the control zone (far away from the SRF).

The theoretical damage-cost curve (Fig. 2) shows that the damage from cyclones could be reduced or avoided through increasing the width of forest. Thus, in this study, we considered the width of the forest as the focal explanatory variable to estimate the damage cost that could be avoided by increasing 1-km width of the mangrove. Thus, after estimating the DCA function, we estimated the total damage that was avoided due to the presence of the SRF in the treatment zone by comparing to the control zone, where there were no mangrove forests. Thereafter, we multiplied the average DCA/household for $1-\mathrm{km}$ width of the mangrove by the total number of households in the treatment zone in order to estimate the protection value of the SRF. Next, we divided DCA for the SRF by its total area $\left(6,030 \mathrm{~km}^{2}\right)$ to calculate the protection value of the mangrove forest per $\mathrm{km}^{2}$ and per hectare. The total DCA (i.e., the protection value of the SRF) was then calculated in USD by using the following equation 3 ;

$$
T D C A=D C A_{H} x N H_{F}
$$

Where, $T D C A$ is the total damage cost avoided, $D C A_{H}$ stands for damage costs avoided per household, and $N H_{F}$ refers the number of households located near the SRF.

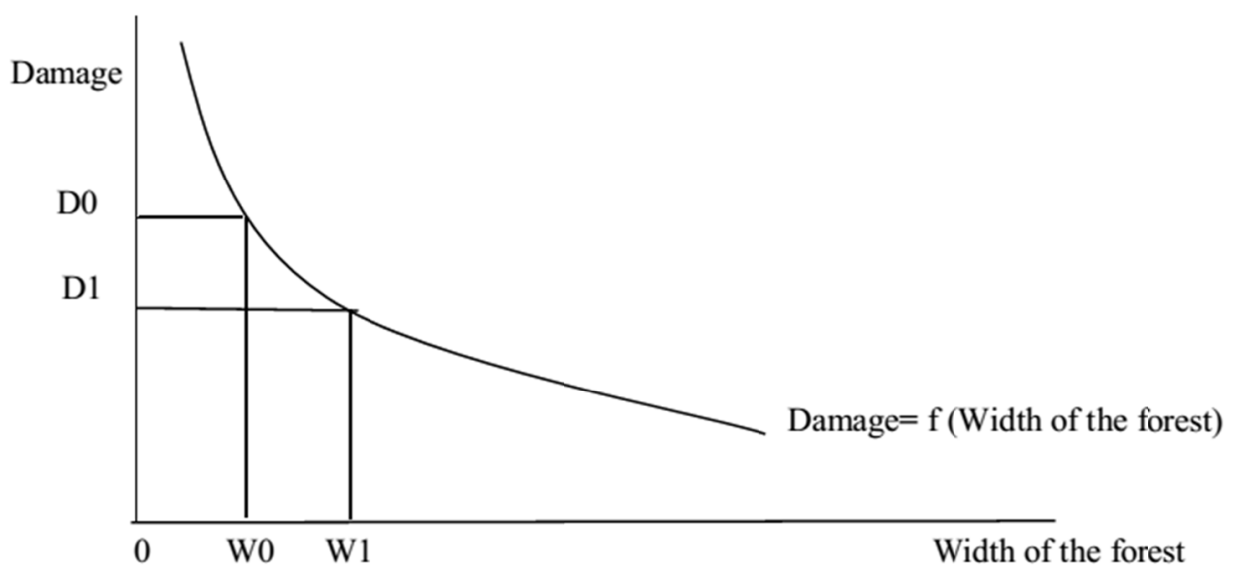

Figure 2. Theoretical damage cost curve of cyclone 
To estimate the current value of the protection service of the SRF, however, we converted the DCA calculated for the year of 2007 into 2015 by using the Consumer Price Index (CPI). For converting the DCA in 2007 to 2015, we used the following formula 4;

$$
\text { DCA in } 2015=\text { DCA in } 2007 x \text { (price level in 2015/price level in 2007) }
$$

\section{Results}

\subsection{Socio-Economic and Demographic Condition of Respondents}

The socio-economic conditions of respondents varied significantly between study sites $(\mathrm{n}=1,525$; Occupation: $\chi^{2}=19.7, \mathrm{df}=8, \mathrm{p}=0.011 ;$ Education: $\chi^{2}=13.9, \mathrm{df}=3, \mathrm{p}=0.003 ;$ Age $\left.: \chi^{2}=77.5, \mathrm{df}=3, \mathrm{p}=0.0001\right)$. More than half of the respondents $(\mathrm{n}=1,525,58 \%)$ were landless across the study zones. Some respondents had their own cultivable land and average land size was $61.62 \mathrm{decimal} /$ individual (one decimal $=1 / 100^{\text {th }}$ of an acre). Agriculture was the major occupation of respondents (39\%) across the study zones. Around $67 \%$ of farmers cultivated land once a year during summer, while the remaining $33 \%$ reported cultivating twice. A majority of the farmers $(95.8 \%)$ grew rice, and the remaining $(2.4 \%)$ grew vegetables as their major agricultural crop. A considerable number of respondents were involved in day-labour activities (19.3\%) and shrimp businesses (13.8\%). Regarding shrimp farming, most of the respondents reported that they did not own $(76.6 \%)$ or even work $(98.2 \%)$ in the shrimp farms. The average size of a shrimp farm was 116.75 decimal, but the farm size was homogenous between the study zones $(\mathrm{F}=3.55, \mathrm{df}=3, \mathrm{p}=0.061)$. The average farm size was larger in the treatment zone (128.63 decimal), while the size was 74.53 decimal in the control zone. The mean annual investment (MAI) per shrimp farm was USD 711.13 and varied insignificantly between study zones $\left(\mathrm{MAI}_{\mathrm{TZ}}=\right.$ USD 714.19 and $\left.\mathrm{MAI}_{\mathrm{CZ}}=\mathrm{USD} 701.59 ; \mathrm{F}=0.005, \mathrm{df}=1, \mathrm{p}=0.945\right)$. The majority of respondents belonged to age groups between 36-45 years (35.3\%) and over 45 years (32.7\%). Among respondents, $10.4 \%(n=159)$ was female. Many respondents (44.3\%) were illiterate or had education below primary level, and the proportion of such groups was relatively higher in the treatment zone (49.2\%) closer to the SRF, while lower in the control zone $(40.5 \%)$, far away from the forest. Very few respondents $(2.9 \%)$ had graduated from university or secondary school. The mean household size was slightly smaller in the treatment zone (5.03 persons/household) than in the control zone (5.10 persons/household), but the variation between study sites was insignificant $(\mathrm{F}=$ $0.53, \mathrm{df}=1, \mathrm{p}=0.465)$. Similarly, the average monthly income per household was smaller in the treatment zone (USD 89.61) than the control zone (USD 101.87) and the household monthly income differed considerably between study sites $(\mathrm{F}=7.29$, $\mathrm{df}=1, \mathrm{p}=0.007)$. The average earnings from agriculture were USD 597.27/year/farmer, which varied considerably between study sites $(\mathrm{F}=9.98, \mathrm{df}=3, \mathrm{p}=0.002)$. The estimated mean annual income per household from agriculture was higher in the control zone (USD 711.71) compared to the treatment zone (USD 420.38). The mean annual income (MAINC) from the shrimp farming was USD $1,014.48 /$ farm, but insignificant between the study zones $\left(\mathrm{MAINC}_{\mathrm{TZ}}=\mathrm{USD} 117.22\right.$ and $\mathrm{MAINC}_{\mathrm{CZ}}=\mathrm{USD}$ $655.89 ; \mathrm{F}=1.69, \mathrm{df}=1, \mathrm{p}=0.195)$.

\subsection{Comparative Assessment of Damages between Treatment and Control Zones during Cyclone Sidr}

\subsubsection{Household Status and Damages of Residential Houses}

Housing patterns of respondents across the study areas varied considerably between study sites $\left(\chi^{2}=228.9, \mathrm{df}=\right.$ $3, \mathrm{p}=0.0001)$. The respondents had one of four categories of houses: kacha/earthen hut $(31 \%)$, tin-shed $(63.2 \%)$, semi-pacca/concrete $(4.4 \%)$ and pacca/concrete (1.4\%). Around one-third $(31 \%)$ of the respondents reported that during cyclone Sidr they lived in kacha/earthen houses. The proportion of kacha houses was greater in the treatment zone $(47.8 \%)$ than it was in the control zone (13.1\%). Conversely, the proportion of tin-shed houses was larger in the control zone $(81.9 \%)$ than it was in the treatment zone $(45.6 \%)$. The average cost of reconstructing houses was USD 725.99/house after the cyclone across the study zones and the repair cost of houses varied significantly between study zones (TZ $=$ USD 624 and $\mathrm{CZ}=\mathrm{USD} 827.34 ; \mathrm{F}=7.19$, df $=1, \mathrm{p}=$ $0.007)$. More than $73 \%(\mathrm{n}=1,525)$ of respondents reported that their houses were located inside the embankment during cyclone Sidr. Among respondents who reported the location of their houses outside the embankment during cyclone Sidr, the proportion was significantly higher in the treatment zone $(29.6 \%)$ than it was in the control zone $\left(23.8 \%, \chi^{2}=6.5, \mathrm{df}=1, \mathrm{p}=0.011\right)$.

\subsubsection{Damage and Losses of Household Assets and Properties}

The majority of the respondents reported that they lost household assets such as television, radio, other electronic items, furniture and solar panels (Table 1).They also reported damage caused to their stored crops, livestock, poultry, and home gardens. The respondents who lived in the control zone faced more damage and losses compared to those living in the treatment zone. The total value of damage and losses of household assets and 
properties varied considerably across the study zones $(\mathrm{F}=8.88, \mathrm{df}=1, \mathrm{p}=0.003)$ and it was higher in the control zone (USD 4,809.22) compared to the treatment zone (USD 2,542.86).

Table 1. Number of people who incurred damage and losses of household assets and properties during cyclone Sidr, obtained from interviews of respondents across the study zones and $\chi 2$ tests of independence between types of zones (i.e., control zone $=$ far away from $S R F$ and treatment zone $=$ near $S R F$ )

\begin{tabular}{|c|c|c|c|c|c|c|}
\hline \multirow{2}{*}{$\begin{array}{l}\text { Damage and losses of household } \\
\text { assets and properties }\end{array}$} & \multicolumn{2}{|c|}{ Study zones } & \multirow{2}{*}{$\begin{array}{l}\text { Total } \\
(\mathrm{n}=1,525)\end{array}$} & \multicolumn{3}{|c|}{ Statistics } \\
\hline & $\begin{array}{l}\text { Control } \\
(\mathrm{n}=740)\end{array}$ & $\begin{array}{l}\text { Treatment } \\
(\mathrm{n}=785)\end{array}$ & & $\chi^{2}$ & $\mathrm{df}$ & $P$ \\
\hline Television/radio/other electronics & 16.9 & 7.0 & 11.8 & 35.9 & 1 & 0.0001 \\
\hline Furniture & 51.5 & 72.5 & 62.3 & 71.5 & 1 & 0.0001 \\
\hline Solar panel & 1.8 & 4.8 & 3.3 & 11.2 & 1 & 0.001 \\
\hline Documents and school books & 18.0 & 20.1 & 19.1 & 1.1 & 1 & 0.285 \\
\hline Ornaments and cash money & 14.1 & 14.0 & 14.0 & 0.001 & 1 & 0.981 \\
\hline Stored crops & 29.7 & 19.5 & 24.5 & 21.6 & 1 & 0.0001 \\
\hline Livestock and poultry & 81.8 & 81.4 & 81.5 & 0.03 & 1 & 0.858 \\
\hline Damage trees around house & 86.8 & 63.6 & 74.8 & 108.7 & 1 & 0.0001 \\
\hline Damage fruits and vegetables & 36.1 & 21.7 & 28.7 & 38.8 & 1 & 0.0001 \\
\hline Others (i.e., fishing tools, boat etc.) & 0.5 & 2.4 & 1.5 & 9.1 & 1 & 0.003 \\
\hline
\end{tabular}

\subsubsection{Damage and Losses of Shrimp Farms and Agricultural Crops}

One-third of the shrimp farm owners $(\mathrm{n}=1,525,68.2 \%)$ reported that cyclone Sidr caused extensive damage to their farms, and the extent of damage was considerably higher in the control zone $\left(71.9 \%, \chi^{2}=9.0, \mathrm{df}=1, \mathrm{p}=\right.$ $0.003)$ than in the treatment zone $(64.7 \%)$. The estimated mean cost of damage and losses caused by cyclone Sidr, incurred from agriculture and shrimp farms together, was USD 1,318.26 across the study zones, but insignificant within study zones ( $\mathrm{TZ}=\mathrm{USD}$ 936.13and $\mathrm{CZ}=\mathrm{USD} 1,863.10 ; \mathrm{F}=1.554, \mathrm{df}=1, \mathrm{p}=0.213$ ).

\subsubsection{Human Casualties}

The proportion of human casualties in terms of death during cyclone Sidr was slightly higher in the control zone $(\mathrm{n}=740,6.8 \%)$ compared to the treatment zone $(\mathrm{n}=785,4.5 \%)$ and it varied significantly between study zones $\left(\chi^{2}=3.8, \mathrm{df}=1, \mathrm{p}=0.05\right)$. Similarly, the rate of injury during the cyclone was slightly higher in the control zone $(19.6 \%)$ compared to the treatment zone $(15.8 \%)$ and varied significantly between study zones $\left(\chi^{2}=4.0, \mathrm{df}=1\right.$, $\mathrm{p}=0.045$ ). More than $5.5 \%$ of respondents reported that they had lost family members. Of the victims who died, $36.8 \%$ contributed financially to their family and only $16.4 \%$ were involved in fishing. Of the victims, who died due to cyclone Sidr's attack $31.3 \%$ were dependent; while $19.4 \%$ were children and $16.4 \%$ were housewives. Among respondents, $17.6 \%$ also reported that their family members were injured during the cyclone Sidr, and more than $88 \%$ of injured persons recovered from their injuries within 3 to 4 months after the cyclone.

Among respondents $(n=1,525), 82.9 \%$ received the warning before the cyclone struck the coast. More than half of respondents $(55.5 \%)$ reported that they heard the warning signal from hand miking conducted by the local government, and among them the proportion was higher in the control zone (70.4\%) compared to treatment zone $(41.4 \%)$ and varied significantly between study zones $\left(\chi^{2}=129.7, \mathrm{df}=1, \mathrm{p}=0.0001\right)$. Only $29.9 \%$ of respondents replied that they heard the warning signal from radio/television circulation, and their proportion was significantly higher in the treatment zone (33.2\%) compared to the control zone $\left(26.4 \%, \chi^{2}=8.6, \mathrm{df}=1, \mathrm{p}=\right.$ 0.003 ). Nearly about $78 \%$ of respondents said that the Red Crescent Society warned them to go to nearest cyclone shelters $\left(\chi^{2}=63.9, \mathrm{df}=1, \mathrm{p}=0.0001\right)$ but more than $60 \%(\mathrm{n}=1525)$ reported actually moving to cyclone shelters. Among respondents who did not move to cyclone shelters, different reasons were mentioned, such as staying in their own home due to the location of the cyclone shelter being far from their house (53.6\%), feeling annoyed to move to the cyclone shelter (53.2\%), not caring about the warning signal (18.8\%), guarding the house for assets $(18.7 \%)$. However, $45.7 \%$ of respondents reported that there was no cyclone shelter near their house, while $21.7 \%$ of respondents reported that they did not appreciate the severity of the cyclone damage. More than $18 \%$ of respondents mentioned that they did not have enough time to move to the cyclone centre after hearing the warning signal. 


\subsection{Economic Valuation of Protection Service of the Sundarban Reserve Forest}

For the economic valuation of protection service of the Sundarban Reserve Forest (SRF), the first step is to estimate the damage function associated with the cyclone Sidr. The estimated results are shown in Table 2.The width of the forest is the core explanatory variable. It is expected that a household's damages reduce with the greater width of the forest and vice versa. The estimated coefficient shows that per household level damage reduces BDT 17,105 (USD 251.54) if $1 \mathrm{~km}$ width of the forest increases and this coefficient is significant below $5 \%$ level (for robust standard errors) and below $10 \%$ level (for clustered robust standard errors). The coefficient of types of household (i.e., tin shed) is significant below to $5 \%$ level, and the coefficient of location of households' dummy ( 1 = house is located inside the embankment and $0=$ otherwise $)$ is statistically significant below to $5 \%$ level. That means houses located inside the embankment faced more damages than those outside of it. One reason for this finding is the unusual height of the storm surge, which allowed water intrusion inside the embankment and caused waterlogged conditions for a long time, since the embankment acted as barrier. As a result, damage was high for those families who lived inside the embankment. The coefficient of the velocity of wind shows that damage increases if the velocity of wind increases, and this is significant below $5 \%$ level of significance. The coefficient of the monthly family income of households is also significant below to $10 \%$ level. Similarly, the coefficient of the distance from the coast is significant below to $5 \%$ significant level and shows that the damage decreases if the distance of the household increases from the coast. In addition, the coefficient of hearing about the signal of the cyclone is insignificant, though it is meaningful that hearing the warning signal reduces household level damages. Furthermore, none of the coefficients of the district dummy variables are significant except the coefficient of Barguna, the omitted reference district. Even the coefficients of Bagerhat and Satkhira are insignificant but meaningful and shows decreasing trend of damage and losses for those districts. The estimated $R^{2}$ shows that the explanatory variables can explain only $6.52 \%$ of variation in the dependent variable. However, for the cross-section data the low $R^{2}$ is not a problem at all. The overall model is statistically significant below to $1 \%$ level of significance with $\mathrm{df}(12,1255)$ for robust model and $\mathrm{df}(12,112)$ for clustered model. So, the model is robust.

Table 2. Estimate of the damage function

\begin{tabular}{llll}
\hline Variables & & Model 1(Robust) & Model 2 (Cluster village) \\
\hline Constant & -1274160 & -1274160 \\
Width & $-17105^{*}$ & $-17105^{* *}$ \\
Velocity & $7257^{*}$ & $7257^{*}$ \\
Mfincome & $36^{* *}$ & $36^{* *}$ \\
Gotsignal & -165318 & -165318 \\
Hlocation $(1=$ inside, 0 o others) & $107340^{*}$ & $107340^{*}$ \\
Housetypes & $\mathrm{M}_{2}$ (tinshed) & $154342^{*}$ & $154342^{*}$ \\
& $\mathrm{M}_{3}$ (semi pacca) & 362793 & 362793 \\
& $\mathrm{M}_{4}$ (pacca) & 743596 & 743596 \\
District dummy & $\mathrm{DD}_{1}($ Bagerhat $)$ & -13860 & -13860 \\
& $\mathrm{DD}_{3}$ (Khulna) & 105593 & 105593 \\
Dist-coast & $\mathrm{DD}_{4}$ (Satkhira) & -22187 & -22187 \\
Number of villages & & $-2545^{*}$ & -2545 \\
$\mathrm{R}^{2}$ & & 118 & 118 (clustered for 103) \\
$\mathrm{N}=1,525$ & 0.065 & 0.065 \\
\hline
\end{tabular}

*refers significant level below to $5 \%$, ** refers significant level below to $10 \%$

While calculating the estimated average DCA/household, we accounted the protection services of the SRF. The estimated regression result (Table 2) shows that, as the width of the forest increases by $1 \mathrm{~km}$, the average household's damage decreases by BDT 17,105 (USD 251.5) in 2007.This estimated value can also be considered as the savings of assets by installing one-kilometre intact forest. In estimating the total protection value of the SRF, we considered the total number of households of three districts (i.e., the treatment zone of this study), which is 1.37 million (Population Census, 2011).

The total estimated DCA is calculated in Table 3, which shows that the DCA as the protection value of the Sundarban is USD 345 million in 2007. Converting the area into square kilometres and hectares, we found that 
the protection value of the SRF is USD $\$ 57,211 / \mathrm{km}^{2}$ and USD 572/ha. Since cyclone Sidr affected Bangladesh in 2007 and the associated household damage costs were estimated based on 2007 market prices, we converted the DCA in terms of 2015 values. Considering 2010 as the base year, and the Consumer Price Indices for 2007 and 2015 respectively as 80.56 and 143.66 (Index Mundi 2016; World Bank, 2016), we converted the DCA from 2007 to 2015, which is USD 90,098/ $\mathrm{km}^{2}$ and USD 901/ha. Thus, the protection value for SRF at 2015 prices stands at USD 543.3 million.

Table 3. Estimated protection value of $1 \mathrm{~km}$ width of the SRF

\begin{tabular}{llll}
\hline \begin{tabular}{l} 
Estimated average damage cost avoided \\
\multicolumn{1}{c}{$/$ house hold }
\end{tabular} & Number of households & Total area $\left(\mathrm{km}^{2}\right)$ & Total area (ha) \\
\hline BDT 17,105 in 2007 (USD 251.5) & $13,71,460$ & 6,030 & 603,000 \\
BDT 30,503 in 2015 (USD 396) & & \\
Total damage costs avoided & USD 345 million (BDT 23,458.8 million) at 2007 value & \\
& Exchange rate USD 1 = BDT 68 \\
& USD 543.3 million (BDT 41,833.6 million) at 2015 value \\
& $\begin{array}{l}\text { Exchange rate is USD 1 = BDT 77 } \\
\text { Protection value of SRF/event }\end{array}$ & 2007 value & USD 57,211/ $\mathrm{km}^{2}$ \\
& 2015 value & USD 572/ ha \\
& & USD 90,098/ $\mathrm{km}^{2}$ \\
\hline
\end{tabular}

\section{Discussion}

This study has explored the importance of the Sundarban mangroves in terms of monetary value for protecting household assets and properties from cyclones and storm surges. Very few studies reported that mangroves help to reduce damage and loss of life during storm surges. We found that the costs and damages incurred in the control zone, away from the Sundarban's mangroves, were greater than the costs and damages for people living near the mangroves. As a result, the intensity of storm surges affected the houses in the Barguna district more intensely than those in the treatment areas (i.e., Bagerhat, Khulna, and Satkhira). Our study has shown that household level damages (USD 251.5) associated with cyclones and storm surges decrease with the increase of one kilometre width of mangroves. Badola \& Hussain (2005) also reported protection standards of mangroves similar to our findings, and they found that the costs and damages caused by the cyclone incurred per household were higher in villages protected by an embankment (USD 153.74) compared to those villages protected by the Bhitarkanika mangrove ecosystems (USD 33.31) in India. In another study, Akber et al., (2018) also noted that the monetary loss associated with the cyclone was USD 1,025 per household in the villages sheltered by mangroves, which was about half compared to those villages not in the shadow of mangroves. Das \&Vincent (2009) reported that villages with greater width of mangroves had considerably fewer deaths than villages with narrower mangroves or no mangroves, and they argue that the width of mangroves determines the degree of protection, since mangrove root systems slow down the flow of water.

Badola et al., (2003) found that having mangroves is more beneficial compared to not having mangroves, after calculating an estimation of cyclone damage avoided by surveying $10 \%$ of the households in 35 villages in the Bhitarkanika Conservation Area on the east coast of India. They also learned that houses and crops are protected by mangroves, given the high frequency of flooding of houses and crop fields without mangrove-covered villages. Das (2011) assessed the protection value of mangrove forests of the Kendrapada district of Orissa in reducing residential house damages from wind and surge during the cyclone of October 1999, and he found that each $\mathrm{km}$ width of the mangroves reduces residential house damages by about INR 1,148/village (USD 17.39) and INR 975,800 (USD 14,784.85) for the entire study area. Das (2011) also estimated the protection value of the forest is INR 51,168/ha. Finally, the findings of the current study show that it has similar findings to the discussed studies. Surprisingly, all of the discussed studies were from India and hence the current study as the pioneering study focused on Bangladesh's Sundarban has huge importance to policy makers.

The current study has estimated the economic value of protection service of the SRF in terms of communities' household assets and property. Thus, as a measure to protect the coastal communities, government should initiate installing intact mangrove forest along with the building of dams/embankments and cyclone shelters in coastal areas. Simultaneously, government can enforce relevant laws to halt further destruction or degradation of mangroves due to anthropogenic activities, in terms of licensing, concessions and punishing illegal activities. 
The estimated protection value of SRF also shows that installation of $1 \mathrm{~km}$ intact mangrove forest can save a considerable amount of loss for each household. For policy formation, government should consider an afforestation program with mangrove plant species such as Avicennia spp., Xylocarpus mekongensis, X. granatum, Sonneratia apetala, Bruguiera gymnorrhiza, Cereops decandra, Nypa fruticans etc. in Barguna district, or any other coastal areas of Bangladesh where forest condition is extremely degraded or poor. This information will help government to consider the net gain over the replacement costs of afforestation.

\section{Conclusion}

The Sundarban has a significant role in protecting coastal communities in south-western Bangladesh. The forest contributes USD 251.5 (as of 2007 consumer price and USD 396 as of 2015 consumer price) per household as protection service during an event like cyclone Sidr. In addition to storm protection, the mangrove also serves as a coastal defence by reducing coastal flooding and erosion. The finding of this protection service indicates that by installing new forests with wider width can protect coastal communities where mangrove forest does not exist or is depleted. Like Barguna and other coastal districts, government can start afforesting mangrove seeds to increase the natural protection from cyclones and storm surges. However, this study considered the protection service of the Sundarban's mangrove, but the estimated value would be much higher if we also considered the defence services against coastal flooding and erosion. To enhance the protection services of the SRF, mangrove ecosystems should be restored in degraded zone, under a well-planned and managed scheme around the coastal areas.

\section{Acknowledgement}

We are grateful to John D. Rockefeller Foundation, Winrock International and USAID for providing financial supports under the USAID Climate Resilient Ecosystems and Livelihoods (CREL) project to conduct this research. We are also very grateful to Paul Kvinta, 573 Cameron Street SE Atlanta, GA 30312, USA for editing the language of this manuscript.

\section{References}

Akber, M. A. et al. (2018). Storm protection service of the Sundarbans mangrove forest, Bangladesh. Natural Hazards, 94(1), 405-418. https://doi.org/10.1007/s11069-018-3395-8

Alongi, D. M. (2002). Present state and future of the world's mangrove forests. Environmental Conservation, 29 , 331-349. https://doi.org/10.1017/S0376892902000231

Badola, R. et al. (2003). Valuing the storm protection function of mangroves: a case study from India. Unedited version, XII World Forestry Congress, 2003, Quebec, Canada. Retrieved from http://www.fao.org/3/XII/0860-B2.htm

Badola, R., \& Hussain, S. A. (2005).Valuing ecosystem functions: an empirical study on the storm protection functions of Bhitarkanika mangrove ecosystem, India. Environmental Conservation, 32, 85-92. https://doi.org/10.1017/S0376892905001967

Bangladesh Institute of Development Studies. (2010). A study of the principal market value chains derived from the Sundarban Reserve Forest. Dhaka: IPAC.

Barbier, E. B. (2007). Valuing ecosystem services as productive inputs. Journal of Economic Policy, 22, 177229. https://doi.org/10.1111/j.1468-0327.2007.00174.x

Barbier, E. B. et al. (2011). The value of estuarine and coastal ecosystem services. Ecological Monographs, 81(2), 169-193. https://doi.org/10.1890/10-1510.1

Brander, L. et al. (2006). The empirics of wetland valuation: a comprehensive summary and a meta-analysis of the literature. Environmental and Resource Economics, 33, 223-250. https://doi.org/10.1007/s10640-005$3104-4$

Das, S. (2011). Can mangroves minimize property loss during big storms? An analysis of house damages due to the Super Cyclone in Orissa. In A. K. E. Haque, M. N. Murty, \& P. Shyamsundar (Eds.), Environmental Valuation in South Asia (pp. 170-210). Cambridge, UK: Cambridge University Press.

Das, S., \&Vincent, J. R. (2009). Mangroves protected villages and reduced death toll during Indian super cyclone. Proceedings of the National Academy of Sciences of the United States of America 106, 18, 73577360.

Erwin, K. L. (2009). Wetlands and global climate change: the role of wetland restoration in a changing world. Wetlands Ecology and Management, 17(1), 71-84. https://doi.org/10.1007/s11273-008-9119-1 
Flather, R. A. (2001). Storm surges. In J. H. Steele, S. A. Thorpe, \& K. K. Turekian (Eds.), Encyclopaedia of Ocean Sciences (pp. 2882-2892). London and California: Academic Press.

Manil, M. H. N., \& Mia, M. A. B. (2007). Effect of Sidr on the Sundarban. Applied Geography, Department of Geography and environment, University of Dhaka, Bangladesh, 24(3), 241-325.

McIvor, A. L. et al. (2012). Reduction of wind and swell waves by mangroves. Natural coastal protection series: Report 1. Cambridge Coastal Research Unit Working Paper, 40 (27pp). Published by The Nature Conservancy and Wetlands International.

Mousavi, M. E. et al. (2011). Global warming and hurricanes: The potential impact of hurricane intensification and sea level rise on coastal flooding. Climatic Change, 104(3-4), 575-597. https://doi.org/10.1007/s10584009-9790-0

Nandy, P. et al. (2007).Effects of salinity on photosynthesis, leaf anatomy, ion accumulation and photosynthetic nitrogen use efficiency in five Indian mangroves. Wetlands Ecology and Management, 15, 247-357. https://doi.org/10.1007/s11273-007-9036-8

Paul, B. K. (2009). Why relatively fewer people died? The case of Bangladesh's Cyclone Sidr. Natural Hazards, 50, 289-304. https://doi.org/10.1007/s11069-008-9340-5

Shine, C., \& Klemm, C. de. (1999). Wetlands, water and the law. Paper no: 38. IUCN Environmental Policy and Law.

Siddiqi, N. A. (2001).Mangrove forestry in Bangladesh. Institute of Forestry and Environmental Sciences, University of Chittagong, Chittagong.

Storch, H., \& Woth, K. (2008). Storm surges: perspectives and options. Sustainability Science, 3(1), 33-43. https://doi.org/10.1007/s11625-008-0044-2

Vincent, J. R., \& Das, S. (2009). Reply to Baird et al.: Mangroves and storm protection: Getting the numbers right. Proceedings of the National Academy of Sciences of the United States of America, 106(40), 112.

Wooldridge, J. M. (2003). Introductory Econometrics: a modern approach. Ohio: Thomson Learning.

\section{Copyrights}

Copyright for this article is retained by the author(s), with first publication rights granted to the journal.

This is an open-access article distributed under the terms and conditions of the Creative Commons Attribution license (http://creativecommons.org/licenses/by/4.0/). 